\title{
Awal Perkembangan Islam Di Pedalaman Jawa Bagian Selatan Berdasarkan Tinggalan Budaya Islam
}

\section{Masyhudi}

Keywords: distribution, dispersal, culture, islam, hinterland, coastal, artifact

\section{How to Cite:}

Masyhudi, nfn. (1999). Awal Perkembangan Islam Di Pedalaman Jawa Bagian Selatan Berdasarkan Tinggalan Budaya Islam. Berkala Arkeologi, 19(1), 117-127. https://doi.org/10.30883/jba.v19i1.797

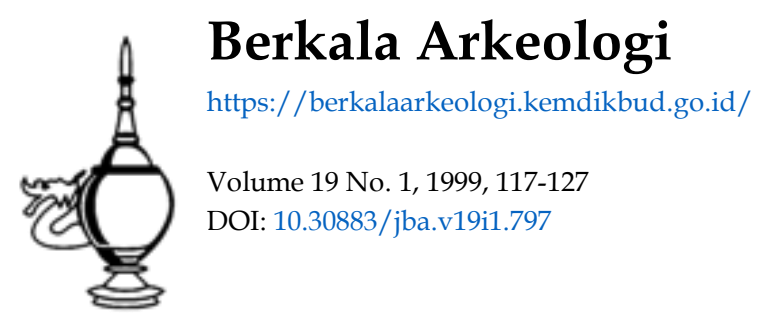

\section{c) (i) (2)}

This work is licensed under a Creative Commons Attribution-NonCommercial-ShareAlike $\underline{4.0 \text { International License. }}$ 


\title{
AWAL PERKEMBANGAN ISLAM DI PEDALAMAN JAWA \\ BAGIAN SELATAN BERDASARKAN TINGGALAN BUDAYA ISLAM
}

\author{
Masyhudi \\ (Balai Arkeologi Yogyakarta)
}

\section{Pendahuluan}

Abad XIII Masehi adalah awal mula munculnya kerajaan Islam di wilayah Nusantara, yaitu di Samudera Pasai yang diprakarsai oleh Raja Pasai I (Al-Malikus-Shalih). Sejalan dengan berkembangan kerajaan Islam, pada periode tersebut para pedagang dan mubaligh Islam mulai memperkuat komunitas Islam secara bertahap dan perlahan, yaitu dengan bergabung kepada masyarakat setempat tanpa menolak situasi sosiokultural dari masyarakat sebelumnya (masyarakat non muslim).

Hal ini merupakan bukti bahwa Islam datang ke Nusantara bukanlah merupakan pamor yang membawa alat perang untuk menaklukkan bangsa Indonesia. Tetapi Islam datang untuk menerapkan ajaran-ajarannya sebagai suatu keharusan melalui strategi yang menentukan tujuan keberhasilan. Bukti lain dalam sejarah perkembangan Islam di Indonesia adalah bahwa Islam datang menerapkan ajaran-ajarannya secara perlahan-lahan, melalui dakwah-dakwah tentang keimanan serta menerapkan unsurunsur kebutuhan pelaksanaan ajaran agama sebagaimana berbaurnya bangunanbangunan (prasarana ibadah), makam dan lain-lain dengan bentuk lama dari suatu bangunan, bahkan terkadang fungsi yang pernah ada.

Pada awal perkembangan Islam, perkembangan plitik, ekonomi dan panggilan agama ikut tampil sebagai motivator yang ikut menentukan corak, penyebaran, pengembangan dan bentuk masyarakat muslim di tiap-tiap wilayah (tempat berkembangnya Islam). Disamping itu tumbuh dan berkembangnya masyarakat Islam juga ditentukan oleh adanya strategi dakwah yang betul-betul bijaksana, karena dalam hal ini didasari oleh ayat al-Qur'an yang terdapat di dalam Surat An-Nakhl ayat 125 :

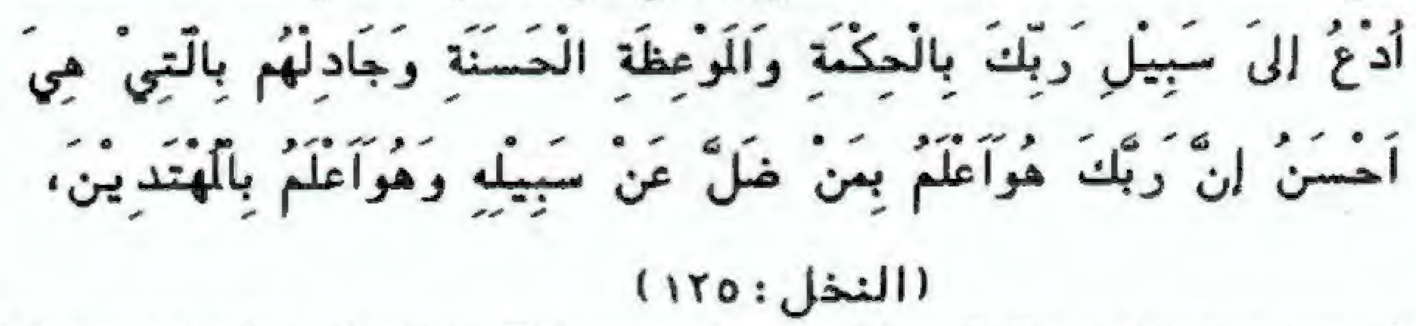

Serulah manusia kepada jalan Tuhanmu dengan hikmah dan pelajaran yang baik dan berdebatlah dengan cara yang baik. Sesungguhnya Dialah Tuhanmu yang lebih mengetahui tentang siapa yang tersesat dari jalan-Nya dan Dialan yang lebih mengetahui orang-orang yang mendapat petunjuk. 
Berkembangnya Islam yang terjadi di Indonesia, secara fisik telah memperlihatkan unsur-unsur budaya Islam sebagai unsur budaya yang berkesinambungan dari unsurunsur budaya pada masa sebelumnya. Dengan adanya unsur-unsur budaya yang berkesinambungan, maka Islam mampu menunjukkan sebagai agama yang akomodatif, demikian halnya keberadaan tinggalan-tinggalan arkeologis dan sejarah , berupa makam, masjid dan naskah-naskah kuna, adalah unsur-unsur budaya materi yang mampu mengungkap sejarah perkembangan Islam di Indonesia.

Sejak akhir abad XV Islam telah menggantikan Hinduisme di Jawa yang merupakan senjata utama dalam kegiatan politik, yaitu dengan munculnya Demak sebagai kerajaan Islam yang paling kuat di tanah Jawa, sehingga sebagian besar masyarakat Jawa dalam abad XVI telah dapat di Islamkan terkecuali masyarakat di wilayah pedalaman dan pegunungan (Dhofier, $1984: 8$ ).

Pernyataan pengecualian tersebut bukan berarti pada masa-masa berikutnya islam tidak berkembang dan tidak tersosialisasi. Akan tetapi pengecualian tersebut agaknya berbeda dengan kenyataan di lapangan. Sebab berdasarkan kenyataan di lapangan, daerah pedalaman dan pegunungan merupakan suatu tempat yang mampu membuktikan bahwa Islam telah dapat berkembang dan tersosialisasi di daerah tersebut. Hal ini dapat dibuktikan melalui tinggalan-tingglan arkeologis dan tinggalan sejarah, berupa makam, masjid dan naskah-naskah kuna.

Beberapa daearah pedalaman di Jawa bagian selatan secara relatif letaknya jauh dari daerah-daerah yang menjadi pusat budaya di Jawa. Sekilas memang nampak bahwa suatu daerah yang jauh dari pusat budaya akan menunjukkan semakin tipisnya budaya dalam berbagai wujudnya. Tetapi kawasan Pegunungan Serayu yang letaknya jauh dari pusat budaya telah memiliki potensi tinggalan-tinggalan fisik yang merupakan komponen-komponen penting untuk mendukung dapat terungkapnya Islam di wilayah pedalaman Jawa bagaian selatan.

Dalam tulisan ini akan memberikan gambaran tentang perkembangan Islam di pedalaman Jawa bagian selatan dan beberapa tinggalan budaya Islam, berupa tinggalan-tinggalan arkeologis dan sejarah yang diduga telah ada sejak awal berkembangnya Islam di Jawa, (abad XV - XVI Masehi). Hal ini dimaksudkan untuk membuktikan, bahwa Islam, pada awal perkembangannya juga terjadi di daerah pegunungan dan daerah pedalaman.

\section{Tinggalan Budaya di Kawasan Pegunungan Serayu}

Kawasan Pegunungan Serayu yang secara administratif meliputi beberapa daerah tingkat II (dua) yaitu Kabupaten Banjarnegara, Kabupaten Purbalingga, Kabupaten 
Kebumen dan Kabupaten Banyumas, mampu menunjukkan potensi kebudayaan dalam berbagai wujudnya.

Wujud daripada kebudayaan ada tiga macam, yaitu :

1. Sebagai suatu kompleks gagasan, ide, nilai, norma, peraturan dan lain sebagainya.

2. Sebagai suatu kompleks aktivitas dan tindakan berpola dari manusia dalam masyarakat

3. Sebagai benda-benda karya manusia, (Koentjaraningrat, $1979 ; 189$ ).

Ketiga wujud kebudayaan tersebut dalam kenyataan kehidupan masyarakat tidak dapat terpisah antara satu dengan yang lain. Akan tetapi karena luasnya pembahasan, bila menyangkut tiga wujud kebudayaaan tersebut, maka dalam urain ini akan difokuskan kepada wujud yang ketiga, yaitu sebagai benda-benda karya manusia dengan tidak mengesampingkan makna dari dua wujud kebudayaan yang lain yang juga dapat disebut sebagai kebudayaan fisik yang tidak banyak memerlukan penjelasan.

Beberapa benda budaya karya manusia sebagai kebudayaan fisik yang terdapat di kawasan Pegunungan Serayu yang diduga ada sejak awal berkembangya Islam di daerah tersebut adalah sebagai berikut ;

\section{Makam}

Makam-makam kuna di kawasan Pegunungan Serayu terdapat di beberapa daerah , yaitu di Kabupaten Banjarnegara, di derah tersebut terdapat makam kuna yang dikenal dengan nama makam Girilangan, yaitu sebuah kompleks makam yang terletak di Desa Gumelem, Kecamatan Susukan, Kabupaten Banjarnegara, dengan tokoh yang dimakamkan Kiai ageng Giring I. Makam yamg lain adalah makam Adipati Wargautama I, yaitu terdapat di Kecamatan Klampok, Banjarnegara.

Di KabupatenBanyumas terdapat sebuah kompleks makam yang dikenal dengan makam Dawuhan. Tokoh yang dimakamkan adalah Adipati Wargautama II (Bupati pertama) Banyumas. Dari kronologi yang ada menunjukkan angka tahun ; 12 Rabiul awal 990 H / 6 April 1582 Masehi. Selain itu, di dalam kompleks makam tersebut juga terdapat makam dari kalangan tokoh penyebar Islam, yang diduga kurang sejaman dengan Wargautama II, tokoh-tokoh tersebut yaitu, Mbah Lambak, Syekh Blimbing, Mbah Binangun dan Mbah Barjat.

Sedangkan makam makam yang lain adalah beberapa makam tokoh penyebar Islam, yaitu makam Kiai Ageng Kajoran, makam Syeh Baribin (Kab. Kebumen) dan makam tokoh-tokoh di kompleks makam Keputihan di Kecamatan Pejagoan, Kebumen. 
Sebagian besar makam-makam tokoh yang ada di kawasan Pegunungan Serayu tidak terdapat indikasi, baik kronologi maupun nama tokoh yang dimakamkan, sehingga keakurasian data dapat dikatakan kurang kuat. Akan tetapi dari sejumlah makam yang ada terdapat dua buah makam yang terdapat indikasi kronologi ataupun nama dari tokoh yang dimakamkan, yaitu makam Kiai Ageng Giring I di situs Girilangan, Desa Gumelem, Kecamatan Susukan, Banjarnegara. Indikasi yang ada menunjukkan suatu kronologi dalam bentuk inskripsi yang terdapat pada bagian bangunan cungkup makam. Inskripsi tersebut tertera pada sisi dalam belandar yang terbuat dari bahan kayu jati yang terdapat di teras dari bangunan cungkup. Inskripsi yang ada telah menunjukkan sengkalan yang berbunyi "bapa pengulu netra jalma", sengkalan tersebut mengacu kepada angka tahun $1298 \mathrm{H}$ yang juga tertulis pada inskripsi tersebut (abad XIX M). Akan tetapi angka tahun tersebut ternyata merupakan angka tahun pemugaran bangunan cungkup makam yang ke dua kali, hal ini diperoleh informasi dari masyarakat setempat. Sedangkan indikasi yang lain tidak ditemukan, bahkan bangunan makamnya sendiri telah mengalami perubahan total, baik dari bentuk maupun bahan yang digunakan, yaitu bentuk jirat segi empat dan di bagian atas jirat terdapat dua buah nisan dengan menggunakan bahan yang sama yaitu lepa.

Satu-satunya makam yang mampu memberikan indikasi tentang kronologi maupun tokoh yang dimakamkan adalah makam yang terdapat di kompleks makam Dawuhan, yaitu makamnya Joko Kahiman atau dikenal dengan sebutan Warga Utama II (Bupati pertama Banyumas I). Makam tersebut berada di dalam sebuah bangunan cungkup baru bersama dengan dua buah makam yang tidak diketahui dengan jelas siapa dua orang tokoh yang dimakamkan tersebut.

Di dalam bangunan cungkup, tepatnya pada dinding di sebelah pintu masuk ke dalam cungkup terdapat inskripsi dengan huruf Arab dan Jawa, sedangkan bahasa yang digunakan adalah Jawa. Inskripsi tersebut berbunyi;

Kyai Adipati Warga Utama II Bupati Banyumas kaping sapisan asmo timur Joko Kahiman winisudha dening Kanjeng Sultan Hadiwijaya ing Pajang, Angasto adipati ing Wirosobo kaping VII ing ari Jumu'ah Kliwon suryo kaping 6 April 1582 Masehi kaleres dawah 12 Rabiul-awal $990 \mathrm{H}$. Suwargi kapareng hambagi Wirosobo dados sekawan wilayah lajeng kasebat Adipati Mrapat.

Menurut inskripsi tersebut, Adipati Wargautama II adalah Bupati Banyumas yang pertama yang sebelumnya bernama Joko Kahiman, Beliau dilantik sebagai adipati yangh ke VII di Wirasaba pada hari Jum'at Kliwon, tanggal 6 April 1582 Masehi yang bertepatan dengan 12 Rabi'ul-awal 990 Hijriyah oleh Sultan Hadiwijaya (Sultan Pajang). 
Berdasarkan sejarah lisan yang berkembang di masyarakat serta disebutkan dalam Babad Banyumas, sebagaimana dikutip oleh Graaf dalam Kerajaan-kerajaan Islam di Jawa disebutkan bahwa Sultan Pajang telah memerintahkan untuk membunuh (menaklukkan) yang dipertuan di Wirasaba yang bernama Wargautama (I) yang dalam kronik jawa menyebutkan tahun 1500/1578 Masehi (Graaf, 1985 : 269).

\section{Masjid}

Secara umum masjid adalah suatu tempat ibadah kaum muslimin dalam arti yang seluas-luasnya, sehingga suatu bangunan masjid dapat berfungsi sebagai tempat penampungan kegiataan pelaksanaan-ajaran-ajaran Islam, sehingga terdapat suatu keterkaitan antara kegiatan keagamaan dengan masjid (Rochym, 1983 : 15).

Sejak awal berkembangnya Islam di Nusaantara , konsepsi tentang bangunan masjid, tidak pernah ada, maksudnya para tokoh pnyebar Islam tidak pernah memberikan konsep atau ketentuan-ketentuan yang tegas mengenai sebuah bangunan masjid. Secara arsitektural masjid-masjid kuna di Jawa pada umumnya mempunyai atap bersusun dengan bentuk menyerupai kerucut. Secara tipologis masjid-masjid kuna tersebut masih melanjutkan pola bangunan yang berasal dari tradisi pra Islam.

Di kawasan Pegunungan Serayu, sejumlah masjid kuna secara umum di bangun berdasarkan tradisi lama, tetapi dari segi penempatanya atau pola keletakan bangunannya bervariasi. Pada umumnya masjid menempati lokasi di lingkungan istana atau tempat pembesar masyarakat setempat dan biasanya untuk masjid-masjid besar terletak di sebelah barat alun-alun. Hal yang demikian terjadi pada masjid agung Demak, Masjid Kraton Yogyakarta dan lain-lain. Bangunan masjid yang pola keletakannya sama dengan pola masjid-masjid kuna yang ada adalah masjid yang terdapat di Kauman, Banyumas. Masjid tersebut pada saat ini dikenal dengan nama Masjid Agung Nur-Sulaiman. Bangunan masjid terletak di sebelah barat alun-alun dan rumah penjara, di sebelah utara bangunan masjid terdapat bangunan perkantoran, sedangkan di sebelah barat dan selatan masjid merupakan permukiman penduduk. Secara pasti bangunan masjid belum diketahui kronologi pendiriannya, karena tidak terdapat indikasi tentang kronologi maupun nama tokoh pendirinya. Bangunan masjid merupakan bangunan beratap tumpang tiga dengan serambi berbentuk limasan, sedangkan pada bagian mustaka masjid berbentuk kerucut. Angka tahun yang terdapat pada sekitar bangunan masjid terdapat pada tembok pagar yang mengelilingi masjid, yaitu angka tahun 1889 dan tahun 1980. Berdasarkan informasi dari narasumber (masyarakat setempat), angka tahun yang pertama (1889) tersebut adalah angka tahun pemugaran yang pertarna kali dilakukan (belum diketahui pihak yang telah melakukan pemugaran), sedangkan angka tahun yang kedua (1980) adalah angka tahun pemugaran yang ke dua kali oleh pihak Pemerintah Daerah Kabupaten Banyumas, dan 
pemugaran yang ketiga dilakukan pada tahun 1997/1998 oleh pihak Suaka Peninggalan Sejarah dan Purbakala, Propinsi Jawa Tengah.. Sementara itu informasi yang ada juga dikatakan bahwa asal-usul masjid berasal dari tanah wakaf Bupati Banyumas yang pertama, yaitu Joko Kahiman.

Sementar itu masjid-masjid yang lain, yaitu ; Masjid Gumelem di Kecamatan Susukan, Banjarnegara, Masjid Saka tunggal di Kecamatan Sempor, Kab. Kebumen, dan Masjid Al-Kahfi di Sumberadi, Kebumen, kesemuanya secara tipologis telah menunjukkan bangunan bangunan lama, tetapi kesemuanya tidak terdapat indikasi tentang kronologi dan nama tokoh yang jelas. Meskipun demikian tinggalan tersebut dapat dijadikan bukti, bahwa di masa lalu Islam telah berkembang di kawasan Pegunungan Serayu yang secara administratif meliputi beberapa daerah.

\section{Naskah}

Naskah kuna adalah bukti sejarah yang memeiliki nilai penting bagi pendidikan dan kebudayaan di Indonesia, tetapi data tekstual tersebut sampai kini tidak begitu banyak muncul sebagai data yang akaurat. Hal ini disebabkan oleh semakin berkurangnya data tekstual yang mampu mengungkap peristiwa peristiwa di masa lampau, selaian itu juga disebabkan oleh sifat benda itu sendiri yaitu mudah bergerak (moveable).

Demikian halnya dengan naskah-naskah kuna yang berangka tahun, sampai sekarang masih jarang ditemukan, sehingga untuk mengukap kronologi suatu naskah, untuk mengetahui kapan suatu naskah ditulis, sampai sekarang baru dapat diperkirakan umur naskah melalui teknologi pembuatan bahan naskah dan watermark yang terdapat di dalam naskah.

Sejumlah naskah kuna yang ditemukan di kawasaan Pegunungan Serayu terdiri dari beberapa jenis, yaitu naskah Al-Qur'an yang meliputi Al-Qur'an tulisan tangan dan Tafsir Jalalain, naskah agama yang terdiri dari Aqidah (tauhid), syari'ah/fikih, dan do'a-do'a. Sedangkan jenis naskah yang lain adalah naskah Historiografi, yaitu naskah yang memuat peristiwa-peristiwa di masa lalu (sejarah lokal).

Naskah historiografi yang ditemukan di kawasan Pegunungan serayu adalah dua eksemplar naskah yang ditemukan di Purbalingga, Jawa Tengah. Naskah tersebut berasal dari Desa Onje, Kecamatan Mrebet Purbalingga. Naskah tersebut dinamakan naskah Onje, karena di dalam naskah memuat nama Onje yang disebut sebagai nama sebuah kadipaten.

Dua buah naskah tersebut adalah naskah yang memiliki muatan yang sama, kemudian setelah dilakukan suatu perbandingan teks dari kedua naskah tersebut, ternyata kedua 
naskah merupakan naskah asli dan naskah salinan. Namun hal yang lebih penting dalam hal ini adalah muatan naskah. Kedua naskah tersebut mengungkap sejarah tentang berdirinya sebuah kadipaten, yaitu Kadipaten Onje, dan pada isi yang lebih penting adalah adanya keterkaitan dengan Kasultanan Pajang, yaitu sekitar abad XVI Masehi.

Dari sejumlah naskah yang ada, naskah Al-Qur'an dan naskah-naskah agama telah memberikan indikasi tentang adanya pendidikan di masa lalu dalam rangka pendalaman terhadap al-Qur'an yang didukung dengan ilmu-ilmu agama yang lain. Demikian halnya dengan naskah historiografi yang ada, telah memberikan gambaran tentsng kepedulian masyarakat di masa lalu untuk dapat dikenang dan diketahui oleh generasi-generasi berikutnya. Di sampimg itu juga telah memberikan gambaran bahwa di masa lalu Islam telah menunjukkan suatu perkembangan yang kuat, bukan saja di kota-kota, tetapi juga sampai ke daerah-daerah pedalaman Jawa, sbagaimana terdapat di daerah pedalaman atau pegunungan Serayu.

\section{Awal Perkembangan Islam di Pedalaman Jawa Bagian Selatan Beserta Tinggalan budayanya.}

Tinggalan-tinggalan budaya yang bernuansa Islam adalah suatu bukti bahwa Islam adalah merupakan suatu agama yang memiliki otoritas penting serta menunjukkan bahwa Islam telah berkembang di suatu wilayah.

Kawasan Pegunungan Serayu adalah sebuah kawasan yang berada di pedalaman jawa bagian selatan. Dalam hal kebudayaan Islam, kawasan tersebut ternyata dapat menunjukkan sebagai kawasan yang potensial mengenai tinggalan tinggalan budaya. Bahkan dari tinggalan-tinggalan yang ada dapat memberikan tanggapan terhadap suatu asumsi, bahwa di daerah pedalaman atau daerah pegunungan tidak terjadi sosialisasi Islam (Dhofier, $1984: 8$ )

Berdasarkan sejumlah data, baik data arkeologi maupun data sejarah yang terdapat di beberpa daerah di kawasan Pegunungan Serayu telah menunjukkan, bahwa di kawasan Pegunungan Serayu yang secara relatif jauh dari pusat budaya, islam telah berkembang dengan pesat, bahkan dari data yang tertua telah menunjukkan suatu kronologi abad XVI Masehi dan sekaligus tokoh-tokoh yang terlibat dalam misi penyebaaran Islam di daerah tersebut.

Misi penyebaran Islam di Jawa berlangsung melalui proses yang tidak mudah serta memakan waktu yang cukup panjang, dimana pada masa pemerintahan sultan Demak, Pajang dan Mataram secara aktif telah melancarkan proses sosialisasi Islam dengan penuh tantangan dan harus dilakukan secara bertahap. 
Abad XVI Masehi adalah merupakan selesainya langkah awal dalam pengislaman terhadap masyarakat Jawa untuk menjadi muslim sekedarnya. Kemudian sebagai langkah tindak-lanjut (sejak abad XVII) merupakan langkah pemantapan, yaitu untuk menjadikan masyarakat betul-betul mejadi masyarakat muslim yang secara perlahan menggantikan kehidupan keagamaan yang lama. Akan tetapi upaya tindak-lanjut tersebut tidak pernah dapat disempurnakan, karena datangnya Belanda di Jawa untuk memonopoli perdagangan dan tidak simpatinya Belanda terhadap penyebaran Islam di Jawa, sehingga langkah untuk memantapkan masyarakat menjadi masyarakat yang betul-betul muslim menjadi terhambat, bahkan akibatnya justru banyak pemimpinpemimpin kraton yang tidak lagi menaruh perhatian terhadap upaya pemantapan tersebut. Di sisi lain, Islam adalah agama yang ajaran-ajarannya diwahyukan Tuhan kepada masyarakat melalui Nabi Muhammad saw. Pada hakekatnya Islam membawa ajaran-ajaran mengenai berbagai segi kehidupan dengan menjadikan Al-Qur'an dan As-Sunnah sebagai sumbernya. (Nasution, $1984: 24$ ).

Berbagai aspek dalam Islam meliputi aspek teologi, aspek moral, aspek mistisisme , filsafat, sejarah, sosial-budaya dan lain sebagainya. Islam di Indonesia pada umumnya dikenal hanya dari aspek teologi, aspek hukum dan aspek ibadah. Sementara itu aspek aspek yang lain seperti sejarah dan sosial-budaya kurang dikenal dan diperhatikan, sehingga pengertian dan pemahaman masyarakat terhadap Islam kurang sempurna. Oleh karenanya, untuk menghindari sekecil mungkin kesalahfahaman atau salah pengertian terhadap Islam, maka perlu pemahaman terhadap aspek-aspek yang lain, termasuk diantara aspek sejarah dan sosial-budaya.

Dalam beberpa catatan sejarah tentang perkembangan Islam di Indonesia menunjukkan, bahwa dalam misi penyebaran Islam yang dilakukan oleh para tokoh terdahulu banyak dilakukan dengan berbagai cara, diantaranya dilakukan dengan menggunakan lambang-lambang budaya dan lembaga pendidikan, sedangkan pendekatan yang digunakan adalah pendekatan sinkretis, yaitu menggunakan lambang-lambang budaya maupun lembaga-lembaga yang ada kemudian diisi dengan muatan-muatan ajaran agama Islam sehingga mudah dicerna dan diterima oleh masyarakat awam.

Berdirinya Kerajaan Demak dengan dukungan para muballing yang dikenal dengan sebutan para wali di Jawa, adalah merupakan suatu keadaan yang telah menjadikan tempat para cendekiawan muslim di Jawa. Dalam kepustakaan Jawa disebutkan; Adalah sudah menjadi kehendak Tuhan. Tersiarnya agama Islam di Jawa bersamaan dengan adanya kekacauan di Kerajaan Majapahit yang menyebabkan kelemahan dan pada akhirnya runtuh sama sekali. Pada masa itu para cendekiawan (kaum intelek Jawa) semakin banyak yang masuk agama Islam, entah karena terbujuk atau karena terpaksa. Itu bukanlah hal yang penting. Yang demikian itulah menyebabkan kaum intelektual berkumpul dalam kalangan agama Islam yang lama-kelamaan menjadi 
pusat kekuasaan dan akhimya menjadi pusat kebudayaan Islam di Jawa. Setelah demikian halnya, maka muncullah kitab-kitab yang berisi tentang keislaman (Poerbatjaraka, 1952 : 96-97).

Di Jawa, hadimya makam, masjid dan naskah-naskah kuna adalah erat hubungannya dengan masalah kedatangan, pertumbuhan dan memuncaknya pranata Islam dalam berbagai segi kehidupan masyarakat Jawa. Sementara itu pada abad XVII - XVIII Masehi dikenal sebagai abad munculnya aliran dalam Islam. Gejala ini muncul ketika terjadi surutnya peranan pusat-pusat kekuasaan Islam yang disebabkan oleh adanya kehilangan peran dan otoritasnya serta munculnya Belanda dan bangsa Eropa lain di Jawa secara politis dan ekonomis (Ambary, 1991 : 11)

Sebagaimana tersebut di atas, bahwa tumbuh dan berkembangnya Islam di Indonesia secara ideologis telah meninggalkan Al-Qur'an dan As-Sunnah, sedangkan secara fisik telah memperlihatkan unsur-unsur budaya Islam sebagai unsur budaya yang berkesinambungan dari unsur-unsur budaya pada masa sebelumnya. Dengan unsurunsur budaaya tersebut, Islam mampu menunjukkan sebagai agama yang akomodatif. Demikian halnya tinggalan-tinggalan arkeologis dan tinggalan sejarah, berupa makam, masjid dan naskah-naskah kuna, adalah unsur-unsur budaya yang mampu mengungkap sejarah perkembangan Islam di Indonesia pada umumnya.

Bukti-bukti fisik yang merupakan tinggalan Islam di masa lalu adalah merupakan budaya materi yang mampu memberikan sumbangan yang berarti. Hal mana budaya materi tersebut telah mengungkap peristiwa-peristiwa dimasa lalu, yang oleh sebagian orang berasumsi bahwa pada awal perkembangan Islam di Jawa, daerah-daerah pedalaman dan pegunungan dikecualikan sebagai daerah yang telah di Islamkan.

Dari sejumlah data yang ada ternyata kenyataannya berbeda dengan asumsi yang ada, sebab data tersebut telah memberikan indikasi bahwa pada abad XVI Masehi, di daerah pedalaman dan pegunungan di Jawa bagian selatan Islam telah berkembang, Perkembangan Islam di beberapa daerah pedalaman ini diprakarsai oleh tokoh dari Kasultanan Pajang, yaitu Sultan Hadiwijaya yang secara politis telah melantik seseorang sebagai tokoh penguasa daerah, yaitu Joko Kahiman (Adipati Wargautama II). Kemudian dalam mengemban tugas, selain tugas pemerintahan dari pihak sultan, Joko Kahiman telah memberikan (wakaf) tanah untuk dibangun atau didiriakan sebuah masjid dalam rangka memenuhi kebutuhan pelaksanaan ibadah dan upaya pengembangan Islam di daerah yang telah menjadi kekuasaannya. Hal yang demikian telah menunjukkan adanya suatu kepedulian dari seorang penguasa untuk kepentingan agamanya. Dalam hal ini dapat dilibat bukti fisik yang sampai sekarang masih ada, yaitu makam Joko Kahiman dan Inskripsi yang terdapat pada dinding di sebelah pintu masuk ke dalam cungkup makam di kompleks makam Dawuhan serta sebuah 
bangunan masjid di Dusun Kauman Desa Saudagaran, Kecamatan Banyumas, Kabupaten Banyumas, (Masjid Agung Nur Sulaiman).

Bukti lain bahwa Islam telah berkembang pada abad XVI Masehi di daerah pegunungan dan pedalaman adalah data tekstual berupa dua buah naskah kuna yang berasal dari Desa Onje, Kecamatan Mrebet Kabupaten Purbalingga, sehingga naskahnya dinamakan Naskah Onje. Berdasrkan muatan yang terdapat di dalam naskah tersebut menunjukkan bahwa Onje dan sekitarnya masih ada keterkaitan dengan Kasultanan Pajang, Dimana Onje dan sekitarnya; Purbosari, Bobotsari, Kertanegara, Kuntowijayan, Bundes mertasanan, Mertomenggalan, Toyarika, Selongo dan Kalikajar (nama-nama tempat lama sebagai tanah perdikan), adalah tempat tempat yang telah diberikan oleh Sultan Pajang sebagai hadiah kepada seorang tokoh yang telah berjasa kepada sultan. Selain itu juga dijadikannya nama Onje sebagai daerah Kadipaten (Kadipaten Onje) dan sekaligus sebagai daerah kekuasaan Pajang pada waktu itu.

Dari tinggalan-tinggalan yang ada sebagaimana tersebut di atas, maka dapat dijadikan sebagai bukti yang dapatmemberikan gambaran atau menunjukkan bahwa pada masa pemerintahan Sultan Pajang (sekitar abad XVI Masehi), dalam peran pemerintahannya maupun dalam rangka misi pengembangan Islamnya telah sampai ke daerah pegunungan dan pedalaman, yaitu di beberapa daerah di Kawasan Pegunungan serayu yang secara relatif termasuk daerah-daerah pedalaman Jawa bagian selatan.

\section{Kesimpulan}

Islam di daerah pedalaman dan pegunungan pada mulanya memang belum diketahui secara pasti, bahwa di daerah-daerah tersebut telah terjadi perkembangan Islam pada awal perkembangan Islam di Jawa, (sekitar abad XV - XVI Masehi). Hal ini disebabkan oleh kurang atau tidak adanya bukti yang kuat, sehingga muncullah suatu anggapan bahwa di daerah-daerah pedalaman dan pegunungan, yang pada waktu itu merupakan daerah yang sulit dijangkau, sehingga ketika Isiam berkembang di Jawa pada masa-masa awal perkembangannya tidak masuk ke daerah-daerah pedalamana.

Alasan yang tepat adalah belum ditemukannya bukti-bukti kuat yang mendukung untuk hal tersebut. Akan tetapi setelah di lakukan beberapa kali penelitian di beberapa daerah pedalaman Jawa bagian selatan ternyata dengan sejumlah data yang diperoleh dapat memberikan sumbangan yang cukup berarti bagi sejarah perkembangan Islam di Jawa, khususnya di daerah-daerah pegunungan dan pedalaman Jawa bagian selatan

Hal ini dapat diketahui melalui tinggalan-tinggalan budaya materi, baik berupa tinggalan arkeologis maupun tinggalan sejarah, yaitu Makam beserta inskripsi, masjid 
dan naskah. Keseluruhan data tersebut merupakan data fisik yang mampu memberikan kejelasan dan memberikan bukti bahwa pada awal perkembangan Islam di Jawa telah sampai ke daerah daerah pedalaman, yang sebelumnya pernah disimpulkan oleh sebagian orang, bahwa pada awal perkembangan Islam di Jawa tidak sampai di daerah pedalaman.

Dengan demikian, berdasarkan bukti-bukti tinggalan budaya yang ada, baik tinggalan arkeologis maupun tinggalan sejarah dapat diketahui dengan jelas bahwa pada awal perkembangan Islam di Jawa, pada abad XV - XVI Masehi bukan saja terjadi di daerah-daerah yang mudah dijangkau (dataran rendah), tetapi juga sampai di seluruh pelosok, bahkan sampai ke daerah-daerah pedalaman dan pegunungan di Jawa.

\section{KEPUSTAKAAN}

Ambary, Hasan Muarif, 1991. Makam-Makam Kesultanan dan Para Wali Penyebar Islam di Pulau Jawa, Aspects of Indonesian Archaeology, No. 12, Jakarta.

Dhofier, Zamakhsyari, 1984 Tradisi Pesantren, LP3ES, Jakarta.

Graaf, De H.J. 1985. Kerajaan-Kerajaan Islam di Jawa, Peralihan dari Majapahit ke Mataram, Grafiti Pers, Jakarta.

Khadim Al-Haramain As-Syarifain, al-Malik Fahd, Al-Qur'anul-Karim watarjamtuhu ilal-lughatil-Indonisiyyah, Al-Qur'an dan Tarjamahnya.

Koentjaraningrat, 1983 Pengantar Ilmu antropologi, Aksara Baru, Jakarta.

Nasution, Harun, 1984. Islam Ditinjau Dari Berbagai Aspek, UI Press, Jakarta.

Poerbatjaraka dan Tarjan Hadidjaja, 1952. Kepustakaan Jawa, Jembatan, Jakarta.

Rochym, Abdul, 1983. Masjid Dalam Karya Arsitektur Nasional Indonesia, Angkasa, Bandung. 